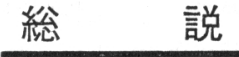

\title{
生化学反応の特徵々
}

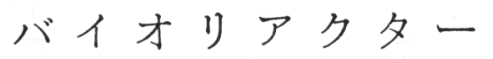

\author{
松野隆一・中西一弘 \\ 京都大学農学部食品工学科 \\ （京都市左京区北白川追分町）
}

\section{Factors Affecting the Performance} of Bioreactors

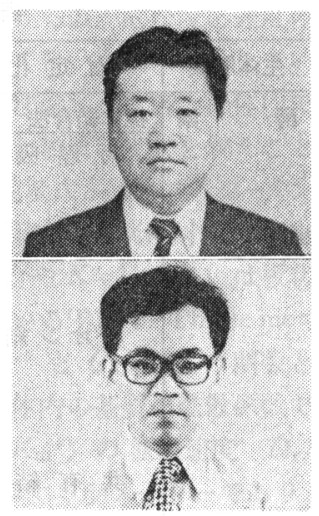

\author{
Ryuichi Matsuno and Kazuhiro Nakanishi \\ Department of Food Science and Technology, Faculty of Agriculture, Kyoto University \\ (Oiwakecho, Kitashirakawa, Sakyo-ku, Kyoto)
}

固定化生体触媒を反応素子として利用するバイオリア クターの特性, あるいは設計に関する基本的事項を固定 化酵素自体と反応器の面に分けて概観した。前者に関し ては活性, 安定性に及ぼす固定化方法, 物質移動, 微小 環境, 固定化による酵素分子の修飾等の影響について示 した。後者に関しては反応器の種類とその特徵について 触れた後, バイオリアクターの設計に際して反応器, 反 応条件の選択がいかに重要であるかを例を示しながら論 じた。

\section{1 緒言}

高等動植物から微生物に至るすべての生物の細胞がそ の生命を維持し増殖生長を続ける過程においては, 酸化 還元, 転移, 分解, 光学分割, 異性化, 合成等ありとあ らゆる種類の化学反応が起こっているが,これらの多様 な化学反応はそれぞれ異なった生体触媒, すなわち酵素 により常温常圧といら温和な条件の下で極めて効率良く 営まれている。すなわち生体細胞は高度に省エネルギー 化, 効率化された一大化学工場とみなすことができる。 またそこで使用される酵素は触媒として完壁にまで無駄 の無い形に設計されており, その高い触媒能と特異性は 化学触媒では到底得難いものである。人類は昔からこの 生体触媒の特性を有用物質の生産のために活用して来 た。例えば食品に関連しては, 有史以前よりビール, ワ イン, チーズの生産等数々の発酵が行われ, 近年に至っ ては酵素（アミラーゼ）を用いたデンプンよりのグルコ 一ス，マルトースの製造等が実施されている。一方医薬 品工業においては放線菌による抗生物質の生産等を挙げ ることができる。この様な物質の生産, 変換に使用され る反応器は “反応特異性が高く, 高能率の触媒である酵
素又は複合酵素系としての微生物を用いる反応器” と定 義される広義のバイオリアクターに属する。しかしなが らこの種のバイオリアクターでは直径 $50 \AA$ 程度の小さ な酵素分子や, $\mu \mathrm{m}$ オーダーの微生物菌体を反応液から 分離して再使用することは極めて困難であった。この難 点を克服するために 1960 年代になって酵素を粒径数十 $\mu \mathrm{m}$ 以上の不溶性担体（固定化担体）に固定化する方法 が開発され，更に近年微生物菌体や細胞オルガネラの固 定化も可能となった。この固定化技術の出現により酵素 や微生物菌体の繰り返し使用, 連続反応が可能となり, その結果一躍生化学反応装置としてのバイオリアクター が体系化されるに至った。すなわちこの固定化生体触媒 を使用する狭義のバイオリアクターは “高性能, 高反応 特異性を持った酵素, 微生物菌体を繰り返し又は連続使 用する反応器”1),22 と定義される。狭義のバイオリアクタ 一に関しては膨大な数の研究報告がなされており，既に 固定化アミノアシラーゼによる Lーアミノ酸の製造等 7 〜8 種類の有用物質生産プロセスにおいて実用化されて いる。バイオリアクターには更に狭義にエネルギー生成 系や酸化還元系と共役した反応系を組み込んだ複合酵素 系の反応器といら定義もある12,2)。これはATP (アデ

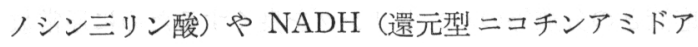
デニンジヌクレオチド) の再生系を組み込んだ反応器 で, それらが分解又は酸化される際に放出されるエネル ギーを使用して, 自由エネルギー消費を伴う合成反応, 還元反応を行い, 付加価值の高い物質を生産する反応器 であり，この実用化への道が開かれれば, 生体触媒利用 の途がさらに広がるものと考えられる。

さて固定化生体触媒をバイオリアクターの反応素子と して使用し, 效率の良い反応プロセスを構築, あるいは 
表-1 種々の固定化法と担体

\begin{tabular}{|c|c|c|c|}
\hline 生体触媒 & 固定化 法 & 担 & 結合の種類 \\
\hline 酵 & $\begin{array}{l}\frac{\text { 担体結合法 }}{\text { 物 理 吸着 法 }} \\
\text { イオン結合法 } \\
\text { 共有結合法 }\end{array}$ & 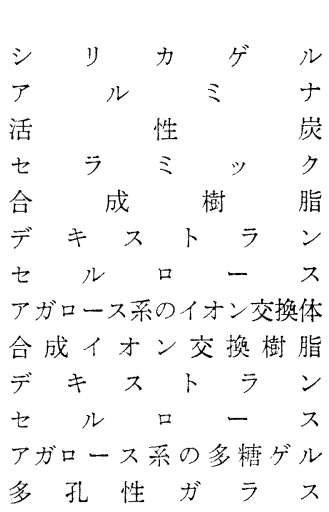 & $\begin{array}{l}\text { 静電気的 } \\
\text { 相作用 }\end{array}$ \\
\hline & $\begin{array}{l}\text { 包括法 } \\
\text { モノマー 法 } \\
\text { プレポリマー法 } \\
\text { ポリマー法 } \\
\text { マイクロカプセル } \\
\text { 橋かけ法 }\end{array}$ & 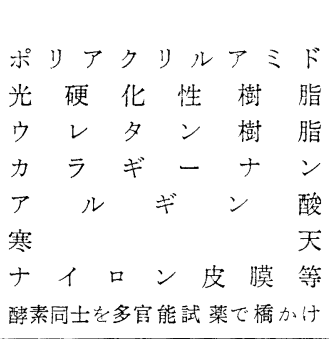 & 化学結合 \\
\hline $\begin{array}{l}\text { 微生物菌体 } \\
\text { 細胞オルガ } \\
\text { ネラ植物細 } \\
\text { 胞 }\end{array}$ & 包 括 法 & 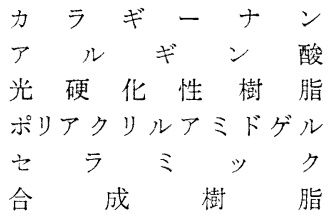 & \\
\hline
\end{tabular}

で担体と結合しているので，高い活性収率 が得られる反面酵素が漏れやすいといら久 点がある。酵素の脱離を防ぐために酵素を 担体に吸着あるいは包括した後グルタルア ルデヒド等の 2 官能基を持った試薬により 橋かけ処理する方法が採られている。プレ ポリマー法では重合時の熱やラジカルの発 生が少ないために温和な条件で酵素をその ままの状態で固定化することができる4。 なお，モノマーを重合する方法においても 固定化時の酵素の失活を少なくするために 放射線照射による低温重合法 ${ }^{5}$ が開発され ている。

微生物菌体, 細胞オルガネラ, 植物細胞 等は酵素に比較して著しく大きいために適 用される固定化法も限定される。現在, 最 もよく用いられている方法は包括法であ る。特にカラギーナン (6), アルギン酸 ${ }^{7)}$, 光 硬化性プレポリマーによるゲル等が優れて いる。この方法の久点であるゲルの機械的 強度, 耐熱性を高くするために硬化剤によ る処理が行われている。数 $\mu \mathrm{m}$ 以上の孔 径をもつ合成樹脂やセラミックス等も担体 として注目され始めている。

\section{$2 \cdot 2$ 固定化酵素の活性に及ぼす因子}

一般に生体触媒（以下特に断らない限り 酵素に着目）は固定化されることにより， 多かれ少なかれ元の遊離酔素とは違った性 質を示す。簡単のためによく知られている 設計する場合には固定化触媒自体の設計と用いる反応装 置の設計といら二つの面に関して充分な配慮が必要であ る。本稿ではこれら設計に際して必要な基礎的事項, あ るいはその特性を生化学反灾の特徵と関連付けながら紹 介する。

\section{2 固定化生体触媒の特性}

\section{$2 \cdot 1$ 固定化方法 ${ }^{3)}$}

酵素の固定方法注大別して担体結合法, 包括法, 橋か け法の三つがある。いずれの場合も本来の目的である反 応液との分離等のハンドリングを良くするために通常数 十 $\mu \mathrm{m}$ 以上の粒子, あるいは膜状の固定化触媒が作ら れている。

表-1 に主な 固定化方法と担体, 特徴等をまとめて示 す。この中でバイオリアクターの実用に適した方法とし ては固定化酵素の場合では主として物理吸着法, イオン 結合法, プレポリマー包括法が挙げられる。物理吸着 法, イオン結合法では比較的硬い担体を選択することが 可能である。またこれらの方法では酵素は比較的弱い力 ミハエリスーメンテン型の反応について考える。溶液中 の遊離酵素による反応は次式で示される。

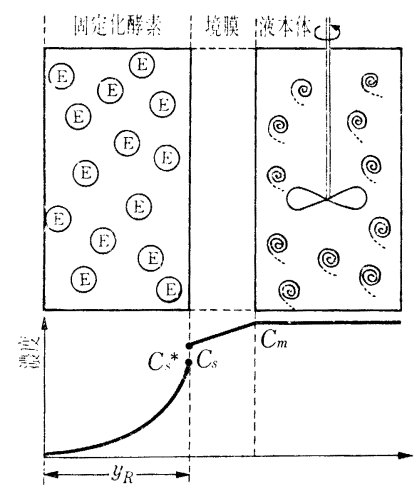

液本体では流体の混合が充分行わ机て扔り 基質濃度は場所によらず一定である。しか し液本体で見られる渦は境膜, 担体内部に は届かない。酵素は担体中に均一に分布し ている。

図-1 固定化酵素担体界酒近傍の樣子 ${ }^{8)}$ 


$$
v=\frac{k_{2} E_{0} C_{\mathrm{m}}}{K_{\mathrm{m}}+C_{\mathrm{m}}}=\frac{V_{\max } C_{\mathrm{m}}}{K_{\mathrm{m}}+C_{\mathrm{m}}}
$$

ここで $k_{2}, K_{\mathrm{m}}, V_{\max }$ は遊離酵素の最大速度定数, ミ八 エリス定数, 最大速度であり， $E_{0}, C_{\mathrm{m}}$ はそれぞれ溶液 中の酵素濃度, 基質濃度を示す。後述する様に酵素を担 体に固定化すると担体内の酵素分子表面近傍の微小環 境, 固定化による䤃素分子の化学修飾等の影響により, $k_{2}, K_{\mathrm{m}}$ の値が変化するので反応速度式は式(2) で表さ れる。通常反応型式そのものが変化することはない。

$$
v^{*}=\frac{k_{2}{ }^{*} E_{0}{ }^{\prime} C}{K_{\mathrm{m}}{ }^{*}+C}=\frac{V_{\max }{ }^{*} C}{K_{\mathrm{m}}{ }^{*}+C}
$$

ここで $E_{0}{ }^{\prime}$ は固定化酵素単位体積当たりの酵素濃度, $C$ は担体内の局所的な基質濃度である。 *印は固定化によ る変化を表す。更に固定化酵素は通常ハンドリングを容 易にするために元の酵素自体の大きさの数千倍以上にな っているので基質の担体内拡散の影響も考慮しなければ ならない。本節ではこれらの因子について述べる。

\section{$2 \cdot 2 \cdot 1$ 物質移動の影響 図-1 に固定化酵素担体界} 面近傍の様子を示す ${ }^{9}$ 。液本体中で汇混合が充分に行わ れているので, 基質濃度 $\left(C_{\mathrm{m}}\right)$ は一定である。一方, 固 定化醳素担体表面近傍にはこの混合の影響が及ばない境 膜が形成されるので，基質はこの境膜を分子抬散により 通過し (外部搪散)，担体表面に到達する。ここで基質 は分配係数 $K=C_{\mathrm{s}}{ }^{*} / C_{\mathrm{s}}$ で定義される分配比で担体内表 面に分配される。更に基質は担体内の間げきを分子拡散 により移動(内部拡散)し，同時に固定化されている䣼素 により反応を受けるので，その結果担体内に 図-1 に示 す様な濃度こう配が形成される。外部抬散の反応速度に 及ぼす影響は物質移動係数により評価されるがッ゙, 反応器 内液本体のかくはんが充分強いか，流速が大きい時は無 視することができる。内部拡散の影響は固体触媒反応の 解析と同様,有効倸数 (ク) で整理されている。りは固定化 酵素の実際の反応速度と担体内部でも担体表面濃度 $C_{\mathrm{s}}$

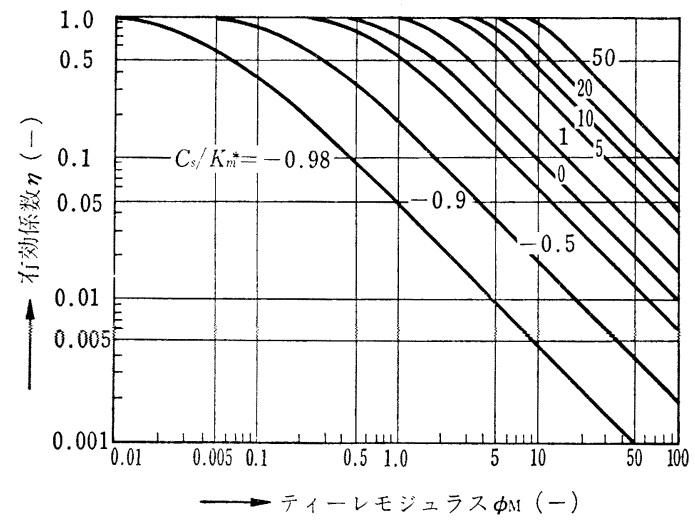

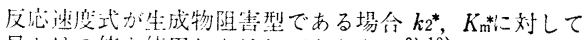
見かけの值を使用しなければならない9，10\}

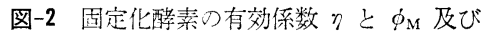
$C_{\mathrm{s}} / K_{\mathrm{m}}{ }^{*}$ 之の関倸 ${ }^{10)}$
で反応が起こると仮定して得られる仮想的な反応速度の 比として定義され，酵素がどのくらい有效に使われてい るかの尺度となる。 $\eta$ に対する理論解は反応と担体内で の基質, 生成物の拡散を考慮した物質収支式を解くこと により得られる。図-2 に反応速度式がミハエリスーメン テン型で, $K=1$ の場合の板状固定化酵素に対する解を 示すが ${ }^{100}$, 他の反応速度式の場合や $K \neq 1$ ，あるいは板状 以外の形状に対しても解かれている11。鸟 Thiele mo dulus $\phi_{\mathrm{M}}=y_{R}\left(k_{2}{ }^{*} E_{0}{ }^{\prime} / D_{\mathrm{s}} K_{\mathrm{m}}{ }^{*}\right)^{1 / 2}$ と $C_{\mathrm{s}} / K_{\mathrm{m}} *$ の関数と して表される。ここで $D_{\mathrm{s}}$ は担体内の基質の拡散係数で ある。 $\phi_{\mathrm{M}}$ は反応速度 $\left(k_{2}{ }^{*} E_{0}{ }^{\prime} \mid K_{\mathrm{m}}{ }^{*}\right)$ の拡散速度 $\left(D_{\mathrm{s}} /\right.$ $\left.y_{R}{ }^{2}\right)$ に対する相対的な割合を示すパラメーターであり， $\phi_{\mathrm{M}}$ が大きくなり拡散が固定化酵素の見脚けの反応速度 を支配するようになる（拡散律速）とクが低下寸る。逆 に, $\phi_{\mathrm{M}}$ が小さくなるか $C_{\mathrm{s}} / K_{\mathrm{m}}{ }^{*}$ の值が大きくなると反 応律速に近づき $\eta=1$ となる。従って固定化酵素の最大 速度 $V_{\max (a p p)}$ は $V_{\max }{ }^{*}$ に一致する。一方ミハエリス 定数 $K_{\mathrm{m}(\mathrm{app})}$ は拡散抵抗の影響を受け, $\phi_{\mathrm{M}}$ が増加す ると $K_{\mathrm{m}}{ }^{*}$ よりも著しく大きくなる。

生成物阻害がある場合は（図-2 において $K_{\mathrm{m}}{ }^{*}$ が負の 場合), 拡散抵抗の增加により担体内部の生成物濃度が 上昇するために $\eta$ は著しく低下寸る。この樣に物質移 動の影響は固定化酵素の反応速度を低下させる傾向にあ るが，基質阻害型の反応 ${ }^{92}$ あるいは逐次反応 ${ }^{122}$ において は逆に拡散抵抗の存在により反応速度を高くすることが 可能である。

$2 \cdot 2 \cdot 2$ 固定化による速度パラメーターの変化 $k_{2}{ }^{*} E_{0}{ }^{\prime}, K_{\mathrm{m}}{ }^{*}$ 值は固定化酵素をすりつぶして $\eta \equiv 1$ の条 件で得られる $V_{\max (a p p)}$ と $K_{\mathrm{m}(\mathrm{app})}$ の值から求めるこ とができる。すなわち $V_{\max (a p p)}, K_{\mathrm{m}(a \mathrm{pp})}$ はそれぞれ $k_{2}{ }^{*} E_{0}{ }^{\prime}\left(V_{\max }{ }^{*}\right), K_{\mathrm{m}}{ }^{*} / K$ に相当する。 $k_{2}{ }^{*} E_{0}{ }^{\prime}, K_{\mathrm{m}}{ }^{*}$ の 值に及湆す因子としては a) 固定化時の酵素失活，b) 立体障害，c）担体内微小環境の変化，d）固定化による 醳素分子の化学修飾が挙げられる。a）に関しては酵素 の失活は all or none であるので $V_{\max }{ }^{*}$ は低下するが $K_{\mathrm{m}}{ }^{*}$ 値は変化しない。高分子基質の場合は基質が活性 部位に近づき難くなるので $K_{\mathrm{m}}{ }^{*}$ 值も変化する (b)。こ の立体障害の影響を除くために酵素分子と担体構成成分 の間に適当な長さのスペーサーを入れることもある。酵 素をイオン交換体に固定化した時は担体内部の $\mathrm{pH}$ が 溶淮中の植と洨なる。通常 $K_{\mathrm{m}}{ }^{*}, V_{\max }{ }^{*}$ 值注担体内 部の $\mathrm{pH}$ に相当する溶液中での値を示すと考えられる。 担体内部の $\mathrm{pH}$ は Donnan の膜平衡式により近似的に 推算される ${ }^{13,14)}$ 。

d）の例では，活性部位の周辺が固定化により修飾さ れて $\mathrm{pK}$ が変化し, $\mathrm{pH}$ のシフトが起こったり, 修飾に よりコンホメーションの凍結が起こりアロステリック性 を示さなくなる場合がある15)。 


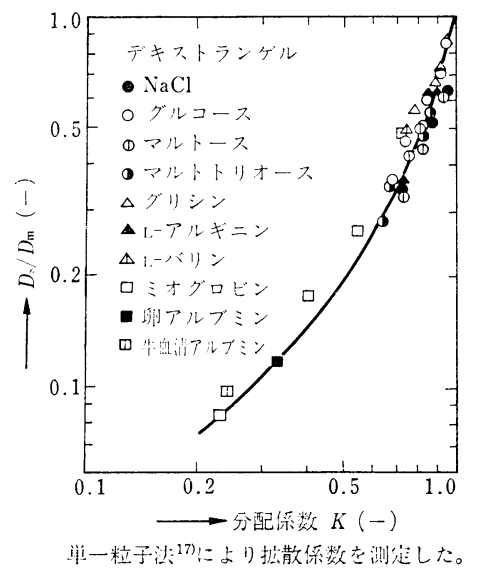

図-3 種々の物質のデキストランゲル中での 拉散倸数之分配係数の関倸 ${ }^{8)}$

$2 \cdot 2 \cdot 3$ 分配係数 基質の担体に対する分配係数 $K$ は主に a）担体のマクロな物理的な構造, b) 静電気的 相互作用，c）親水性あるいは疎水性相互作用によって 影響を受ける。a）の場合は担体構成成分と基質の化学 的相互作用の少ない場合で, 担体内の網目構造や基質の 大きさに依存する。b) の場合は基質と担体のイオン的 相互作用の場合で，同符号の場合はお互いに反発するの

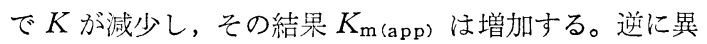
符号の場合は $K_{\mathrm{m}(\mathrm{app})}$ は低下する ${ }^{13), 16) 。 フ ゚ レ ホ ゚ リ マ ー ~}$ 法による固定化においては，プレポリマーの疎水性ある いは親水性度を変化させることにより担体の疎水性度を コントロールできる。例えばステロイドの変換反応にお いては担体が疎水性の場合に低い $K_{\mathrm{m}(\mathrm{app})}$ が得られ, 反応が効率良く行われた4)。

$2 \cdot 2 \cdot 4$ 基質の桩散係数 Thiele modulus 中の $D_{\mathrm{s}}$ の合理的な推算法は確立されていない。測定法は大別し て4つの方法があるが，詳細については総説 ${ }^{17)}$ ていただきたい。図-3 は種々の拡散物質のデキストラ ンゲル中での㹡散係数の 測定結果を示す ${ }^{8)}$ 。 $D_{\mathrm{s}}$ と分子 拡散係数の比が， $K$ に対してプロットしてある。抾散 物質とデキストランゲルとの相互作用は小さいので $K$ は担体棈成成分による立体障害の程度を表す。 $K$ によっ て $D_{\mathrm{s}} / D_{\mathrm{m}}$ がよく相関されているからゲル中での $D_{\mathrm{s}}$ の 低下の原因は主として昖散物質の移動が網目構造に妨げ られるために起きると考えられる。アクリルアミドゲル 中で汸ゲル棈造の違いのため， $D_{\mathrm{s}}$ の変化は異なった挙 動を示す日7)。

$2 \cdot 2.5 \eta$ 值の推算 $\phi_{\mathrm{M}}$ 中のパラメーター, $y_{R}, D_{\mathrm{s}}$, $k_{2} E_{0}{ }^{*}, K_{\mathrm{m}}{ }^{*}$ と $K$ の值を何らかの方法で推算すること ができれば $\eta$ 值が 図-2 より算出され，机上の計算によ り固定化酵素の活性をコントロールできることになる。 この試みは低分子基質で，固定化担体が韭イオン性の場
合には成功しているが'18)，高分子基質や担体がイオン性 の場合は検討の余地が残されている。

$2 \cdot 2 \cdot 6$ 担体内酵素分布 以上の取り扱いでは担体 内で酵素分布は均一であると仮定したが，固定化法によ っては必ずしも均一とは限らないので注意を要する19), 20)。一方, 酵素を担体内で適当に分布させたり ${ }^{5)}$, 種類の 異なった酵素を場所を変えて固定化することにより ${ }^{21)}$, 更に効率の良い目的に合致した固定化酵素の設計も可能 である。固定化増殖菌体では増殖と酸素の担体への拡散 速度のバランスに従って, 自然に菌体が担体表面に集中 してくるようになる ${ }^{22)}$ 。

\section{3 安定性に及ぼす因子}

バイオリアクターが実用化されるか不かはその反応素 子である固定化生体触媒の安定性にかかっている。事実 工業化されたプロセスではいずれの場合もその反応の半 減期は数か月以上に達している。安定性に及ぼす因子と しては物質移動, 固定化方法, 担体の種類等が考えられ る。

$2 \cdot 3 \cdot 1$ 物質移動の影響 一般的に固定化酵素の失活 速度は内部拡散の影響が大きくなる程小さくなる。すな わち未失活な状態でのクが小さい程酵素は安定化され る。これは前節で述べたように未失活な状態では担体粒 子表面近傍の酵素のみ有効に使われ, 失活が進むに従っ て内部の酵素も反応にあずかるようになるために生じる 見かけの現象である。失活速度が一次反応で表される場 合, 固定化酵素の見掛けの失活速度定数 $k_{\mathrm{d}(\mathrm{app})}$ は内部 拉散の影響により $\sqrt{k_{\mathrm{d}}{ }^{*}}$ の值に近づく。ここで $k_{\mathrm{d}}{ }^{*}$ は 拡散の影響のない場合の固定化酵素の失活速度定数であ る。酵素が安価な場合には，この現象を有効に利用して 操作安定性を増すことができる。基質濃度が高くなると 酵素は基質の保護効果により安定化される場合が多い が，拡散抵抗による安定化の効果は減少する ${ }^{23) 。 ~}$

$2 \cdot 3 \cdot 2$ 固定化方法の影響 ここでは拡散の影響がな い場合の固定化酵素の安定性に及ぼす固定化方法の影響 について述べる。酵素は固定化されることにより安定性 が増加する場合が多く，最近ではその安定化の機構を探

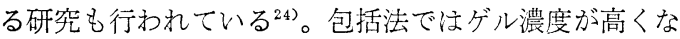
ると安定化される場合が多い。ポリメタクリラートゲル 包括法により固定化されたトリプシン ${ }^{25)}$ 忟ゲル濃度が25 \%以上になるとゲル中の酵素の拡散係数の著しい低下に より自己消化の現象が全くみられなくなる。さらにゲル 濃度を高くすると (40\% 以上) 算分子的な熱失活も抑え られるが，これは酵素分子とゲル構成成分間の相互作用 の効果により (多点結合), 酵素分子のゆらぎが減少する ためであると推論されている。一方，イオン結合法，物 理吸着法では逆に相互作用が強過ぎて, 安定性が低下す る場合もある。更に前者では担体内の $\mathrm{pH}$ 変化の影響 も考慮しなけ机ばならない。共有結合法の場合は酵素を 
その本来のコンホメーションを変化さ せない様に担体と多点結合させると堅 い構造となり, その結果著しく安定化 される場合がある。Martinek らはこ のスキームのもとに共有結合法 ${ }^{26), 27)}$, 包括法 (前述) ${ }^{25)}$, 分子内橋かけ法 ${ }^{23)}$, ${ }^{29}$ 亿括汀る安定化の方策について検討 を行った。共有結合法では多点結合の され方に分布が生じることが明らかに されている ${ }^{300}$ 。そのために遊離酵素の 熱失活過程は一次反応で表せるのに固 定化すると一次反応に従わなくなる。
セファロース CL-4B に共有結合された $\alpha$-キモトリプ シンやグルコアミラーゼの熱失活実験の結果は, 熱失活 の活性化自由エネルギーがガウス分布すると仮定したモ デルにより定量的に説明された ${ }^{31)}$ 。

ハ-カラギーナンに包括された Brevibacterium flavum の場合 ${ }^{22}$ フマラーゼの様な膜酵素の安定性は増加する が,この機構も多点結合によるものと同一と考えられて いる。

長時間反応を行う場合は酵素の担体からの漏れ, 脱離 も重要な因子である。吸着法, 包括法, イオン結合法で は, 担体中の酵素濃度は外液酵素濃度との平衡関係によ り支配されるので, 連続的に基質を流すと酵素は多かれ 少なかれ担体より脱離することになる。共有結合法にお いても, 加水分解により酵素と担体との結合が切れるこ とが知られている。

\section{3 反応器の特性}

\section{$3 \cdot 1$ プラグフロー型（PFR） と完全混合型反応器 (CSTR)}

連続反応操作を行う際の反応器としてプラグフロー型 (Plug flow reactor; PFR) と完全混合槽型 (Continuous

表-2 固定化生体触媒の工業的利用例 ${ }^{36)}$

\begin{tabular}{|c|c|c|}
\hline 固定化生体触嫫 & 用 & $\begin{array}{l}\text { 工業化開 } \\
\text { 始の時期 }\end{array}$ \\
\hline $\begin{array}{l}\text { 固定化アミノアシラーゼ } \\
\text { 固定化 Escherichia coli } \\
\text { (アスパルターゼ) }\end{array}$ & $\begin{array}{l}\mathrm{DL} \text {-アミノ酸の光学分㓶 } \\
\text { L-アスパラギン酸の製造 }\end{array}$ & $\begin{array}{l}1969 \text { 年 } \\
1973\end{array}$ \\
\hline 固定化ペニシリンアミダーゼ & 6-アミノペニシラン酸の製造 & 1973 \\
\hline 固定化グルコースイソメラーゼ & 異性化糖液の製造 & 1973 \\
\hline $\begin{array}{l}\text { 固定化 Brevibacterium ammoniagenes } \\
\text { (フマラーゼ) }\end{array}$ & Lーリンゴ酸の製造 & 1974 \\
\hline 固定化ラクターゼ & 低乳糖乳の製造 & 1977 \\
\hline $\begin{array}{l}\text { 固定化 Pseudomonas dacunhae } \\
\text { (L-アスパラギン酸 } \beta \text {-脱炭酸酵素) }\end{array}$ & Lーアラニンの製造 & 1982 \\
\hline
\end{tabular}

stirred tank reactor; CSTR) があるが, これらは基質 の反応器内での滞留時間分布, 言い換えると混合状態に 関して両極端を示す反応器である。すなわち PFR では 理想的な場合, 反応器内での基質の混合が全くないの で, 基質濃度は反応器入口から出口に向かって順次低 下し，生成物は逆に増加する。一方，CSTR で注充分な 混合が起こっているので, 反応器内の基質, 生成物浱度 は一様である。

\section{$3 \cdot 2$ 種々の反応器}

図-4に実際に固定化生体触媒に対して用いられてい る種々の反応器を, 装置内の混合の度合いを示す尺度と なるペクレ数 $\left[P_{\mathrm{e}}=D_{\mathrm{L}} /(Z u)\right.$, ここで $D_{\mathrm{L}}$ : 装置内の混 合拡散係数, $Z$ : カラム長, $u$ : 線速度] のお抢よその值 によって並べてある。CSTR, PFR を両極端として, 固 一液系流動層, 液一気-固三相流動層, 膜型反応器, 回転 円盤型反応器がその中間に位置している。基質阻害が強 くない限りは, 反応器内の混合が少ない程, 固定化触媒 単位体積当たりの反応速度は増加するので彸率が良い。 粘性の高い基質溶液には反応器内の混合による若干の効 率の低下を犠牲にしても圧力損失ぶ大きくならない流動 層を利用するのが有効である。回転円艋型や三相流動層 $\begin{array}{lll} & S & \text { अ基質の一つや生成物が気体の場 } \\ & \mathrm{P} \quad \text { 合に適する }{ }^{33)} \text { 。の例としてポリ }\end{array}$

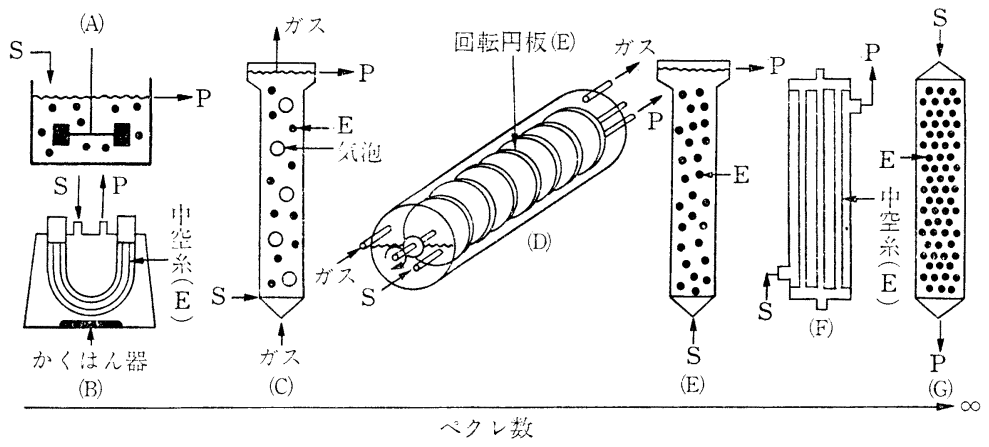

$\mathrm{S}$ ：基所, $\mathrm{P}$ ：生成物, $\mathrm{E}$ ：固定化酵素または酵素溶液

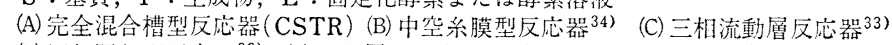

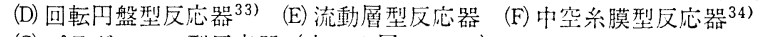

(G) プラグフロー型反応器 (充てん層, PFR)

図-4 バイオリアクターとして使用される種々の反応器3 アクリルアミド固定化 Pseudo= monas ovalis によるグルコース よりのグルコン酸の製造や固定化 酵母によるエタノールの生産等が ある ${ }^{33)}$ 。膜型反応器はリパーゼの 様に踈水性膜に強く吸着する酵素 を使用する場合や，酵素の固定化 が困難な場合, あるいは補酵素を 必要とする複合酵素系の反応の場 合に使用される。基質の膜透過速 度を高めるため, 膜の両側の圧力 を交互に上げ下げする方法（プレ ッシャースイング法 ${ }^{35)}$ ) も考案さ 
れている。

\section{4 反応の特徵と反応器の選択}

固定化生体触媒をバイオリアクターの反応素子として 用い，効率の良いバイオリアクターを設計するには個々 の酵素, 微生物反応の特徵を允分に把握した後, それに 最適な反応器の選択, 反応条件の設定を行わ礼ばならな い。

\section{$4 \cdot 1$ 工業化された例の場合}

表-2 に示す既に工業化されている7種類の反応プロ 七スにおいても ${ }^{36)}$, その研究段階において, 固定化法の みならず反応器, 反応条件等の選択に関して数多くの検 討が行われている37)。世界最初の工業化例である固定化 アミノアシラーゼによる DL-アミノ酸の光学分割にお いては, 反応器の選択, 反応条件の設定に関して種々の 反応工学的な検討がなされた。固定化 Esherichia coli による Lーアスパラギン酸の製造においては基質への $\mathrm{Mn}^{2+}$ 等の二価金属イオンの添加と固定化法の改良によ り, 連続反応時の活性半減期が飛躍的に延びたことが成 功の主因であった。また，このプロセスでは酵素反応に より生じる反応熱を調節するために多段式, 放熱型のカ ラムを使用している。固定化ラクターゼによる牛乳中の ラクトースの分解反応ではカラムの微生物污染を避ける ために低温 $\left(5^{\circ} \mathrm{C}\right)$ で反応を行い, 定期的にカラムを洗浄 するという方策をとっている ${ }^{38)}$ 。固定化 Pseudomonas dacunhae による L-アスパラギン酸からの L-アラニン の反応においては, 最大の問題であった反応に伴う $\mathrm{CO}_{2}$ ガス発生に基づく $\mathrm{pH}$ 変化を加圧反応装置を用いるこ とにより抑えることが可能となった。

また，工業化の寸前にある固定化（増殖）酵母による グルコースからのエタノールの製造に扮いては, 高濃度 の糖による菌体の増殖阻害を少なくするために循環法, 多段供給法等の方法が試みられている ${ }^{37)}$ 。

研究室レベルでの実験例においても個々の生化学反応 に適した反応条件の選択により, バイオリアクターの性 能が著しく改良された例がある。また，この観点から反 応装置に関して種々の提案がなされている。以下にこれ らの例を示す。

\section{$4 \cdot 2$ 固定化ラクターゼによるラクトースの加水分解 -PFR と CSTR の操作安定性の違い一}

Duolite ES-762 に固定化した Bacillus circulans 起 源のラクターゼにより $4.56 \%$ ラクトース溶液の連続 加水分解を $40^{\circ} \mathrm{C}, \mathrm{pH} 6.0$ で行った ${ }^{39)}$ 。図-5 (下図) に PFR による実験結果を示す。図よりわかるように活性 が日とともに低下している。しかし 14 日目よりバッフ アーによる洗浄と反応を繰り返すと, 洗浄の度に活性が 回復することから先の活性の低下は不可逆的でないこと がわかる。この奇妙な現象の起こる原因を検討したとこ

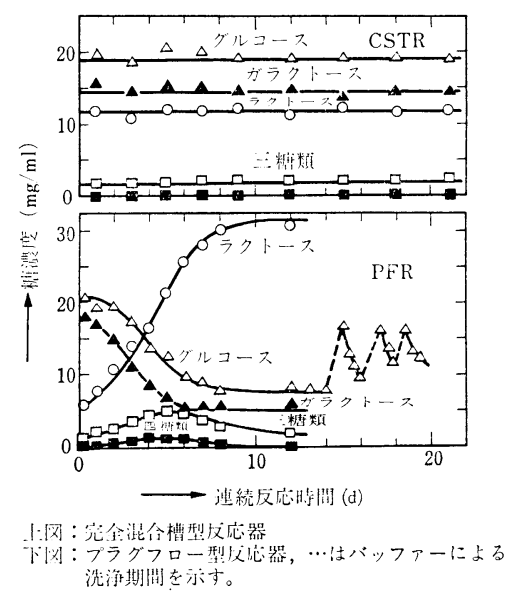

图-5 固定化ラクターゼによるラクトースの 連続加水分解反応 ${ }^{-3), 399}$

ろ, 副反応として起こる転移作用によって生成するオリ ゴ糖にあることがわかった。バッチ反応によるとオリゴ 糖はラクトースの加水分解率が 30 50\% 付近で最も蓄 積し, 反応終期に再び加水分解されることがわかってい る。操作を安定に行うにはオリゴ糖の生成しない条件を 選べばよいから，まず高分解率で行うことを考える。し かし, PFR では反応器出口で高分解摔にしても, カラ ムの途中にオリゴ糖が蓄積し 活性を下げる。それでは CSTR ではどうであろらか。CSTR は反応効率は悪い が, 反応器内で漘度が均一になっているから, 高分解率 にさえしておけば，オリゴ糖のレベルを低く保てる。図 -5 (上図) は CSTR による結果であるが予想通り操 作安定で, 活性の低下は認められない。

4.3 酵母の解糖系酵素群及びキナーゼを用いたアデ ノシンよりの ATP の連続再生一生成物 リサイクル 膜 型 PFR一

酵母より抽出した解糖系醅素群及びキナーゼを用い膜 型 PFR にてグルコースをエネルギー源としてアデノシ ンより ATP 連続再生した ${ }^{40)}$ 。本系に注少なくとも 14 の酵素が含まれるが, 反応の中間生成物がそれらの 熱失活に対し保護作用を示すことがわかった。又，本系 の反応をスムースに進行させるには, 反応初期に最終生 成物である ATP や中間生成物であるフラクトースニ リン酸 (FBP) 等の高エネルギー化合物がある濃度以上 含まれていなければならないこともわかった。PFRを 採用しているので反応器入口には中間生成物がなく, 酵 素の保護や, 必要濃度以上の高エネルギー化合物の確保 ができない。このような場合, 反応器の出口あるいは中 間から生成物又は中間生成物を抜き出し, 反応器入口に 再循環させると, 操作の安定性に著しい効果がある40)。 

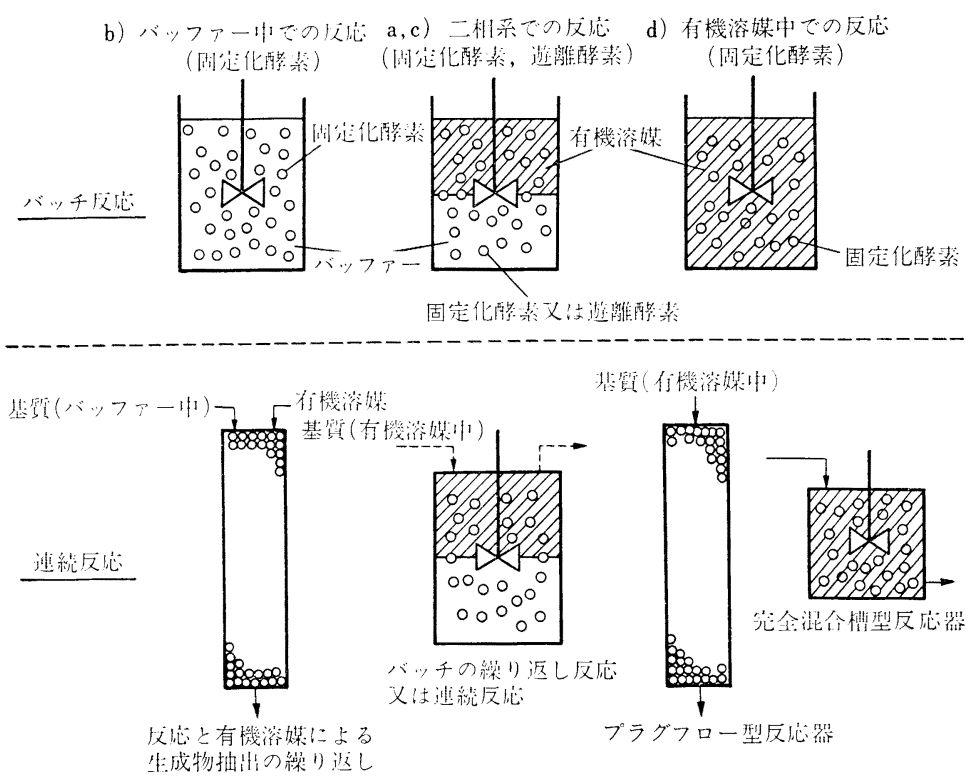

図-6 ペプチド合成反応に対する種々の反応器 ${ }^{44)}$ 上図はバッチ反応, 下図は連繶反応のための反応方式を示す。

不溶性の基質セルロースとセルラーゼの反応において は，セルラーゼがセルロース繊維の表面に結合するばか りでなく, 内部までにも抾散し吸着し加水分解を行う。 また可溶性の生成物が反応を著しく阻害し, セルロース からの酵素の脱着を促進する ${ }^{41)}$ 。セルラーゼが不溶性基 質に吸着することから，一種の固定化酵素と見なすこと ができ, 連続反応を行らことが可能であるが分解率を高 めると，生成物により反応速度が低下するばかりでなく 酵素の脱着も起こる。もし, 生成物を基質として利用す る第二の反応器との間に反応液を高速で循環させること ができれば，七ルラーゼ反応の生成物蕽度を低く保つこ とができ, 反応速度, 酵素の脱着防止の両面での解決が 計れる ${ }^{42)}$ 。

\section{$4 \cdot 5$ プロテアーゼによるペプチド合成一有機溶媒に} よる抽出反応器一

プロテアーゼ（サーモライシン）の加水分解反応の逆 反応を利用してペプチドを合成する反応に対して，高い 合成収率が得られ，しかも反応の連続化に適した反応器 の検討を行った。この観点から a) 遊離酵素を水相に封 じ达め, 水不溶の有機溶媒を添加してエマルション状態

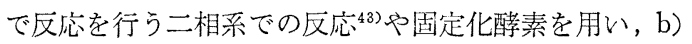
バッファー中，c）二相系，d）有機溶媒中で行う方式が 考えられた ${ }^{44)}$ (図-6)。d）の方式も担体内（水が存在す る）を水相と考えると二相系反応に相当する。a，c）, d) の方式において高い収率が得られた。またここれら の方式では反応をスムースに行らためには基質, 生成物 の二相間の分配, 分配に基づく $\mathrm{pH}$ 変化を充分に把握す るーとが要である。 3, 1913 (1964)
4.6 固定化グルコースイソメラ 一ゼによるグルコースの異性化一分 離装置との組み合わせ一

フラクトース含量がグルコースよ り上回る高果糖異性化糖は，グルコ ースイソメラーゼの反応の平衡がフ ラクトース濃度 : グルコース濃度が 1:1 であるからどうしても分離操 作と組み合わせて製造しなければな らない。分離操作に伴ら生成物の希 釈をできるだけ抑えるべく，イソメ ラーゼカラムを組み込んだ擬似移動 層型製造装置が考案されている45)。

\section{5 結言}

以上述べてきた様にバイオリアク ターの設計に関しては固定化酵素自 体の設計とそれを用いる反応器の設 計という $2 つ の$ 面があるが，いずれ についても過去 20 年間のデータの 蓄積の結果, その基本的事項に関してはかなり体系化さ れてきた。一方，生化学反応は実に多種多様であり，又 そこに関与する酵素の性質に関しても未知な点が多い。 バイオリアクターの設計に際してはまず生化学反応と関 与する酵素の性質を充分に把握した上で体系化されてい る反応工学の手法を適用することが肝要である。

(昭和 59 年 6 月 20 日受理)

文献

1）福井三郎, 山根恒夫 “B. アトキンソン著, バイオリアク ター微生物生化学反応器” の訳者のはしがき, 産業図畫 (1977)

2) 今堀和友, 発酵之工業, 35, 3 (1977)

3）千畑一郎, 土佐哲也, “酵素工学”, 福井三郎, 千畑一郎, 鈴木周一編, 東京化学同人 (1981) p. 157

4）田中渥夫, 園元謙二, 細胞工学, 2, 360 (1983)

5) I. Kaetsu, M. Kumakura, M. Yoshida, Biotechnol. Bioeng., 21, 679, 847, 863 (1979)

6) I. Takata, T. Tosa, I. Chibata, J. Solid-Phase Bio= chem., 2, 225 (1977)

7) 福島 達, 村山浩司, 藤原康晶, 平岩章良, 山出和弘, 日本醗酵工学大会要旨集，(1980） p. 133

8) 松野隆一, 中西一弘, 細胞工学, 2, 343 (1983)

9）松野隆一, “固定化酵素” 千畑一郎編, 講談社サイエンテ イフィク (1974) p. 225

10) G.W. Roberts, C.N. Satterfield, Ind. Eng. Chem. Fundam., 4, 228 (1965)

11）山根恒夫, “生物反忘工学” 産業図書 (1980)

12) K. Mosbach, B. Mattiasson, Acta Chem. Scand., 24, 2093 (1970)

13) L. Goldstein, Y. Levin, E. Katchalski, Biochemistry,

14) S. Adachi, Y. Kawamura, K. Nakanishi, R. Matsuno, T. Kamikubo, Agric. Biol. Chem., 42, 1707 (1978) 
15) C.A. Enns, W. W.-C. Cham, J. Biol. Chem., 253, 2511 (1978)

16) C.W. Wharton, E.M. Crook, K. Brocklehurst, Eur. J. Biochem., 6, 565 (1968)

17) 松野隆一, 中西一弘, 化学工学, 43, 283 (1979)

18) K.F. Nigan, S.H. Lin, Biotechnol. Bioeng., 18, 1623 (1976)

19) S.W. Carleysmith, P. Dunnli, M.D. Lilly, Biotechnol. Bioeng., 22, 735 (1980)

20) S.W. Carleysmith, H.B. L. Eames, M.D. Lilly, Bios technol. Bioeng., 22, 957 (1980)

21）日比野健, 崎山高明, 中村厚三, 矢野俊正, “日本農芸化 学会講演要旨集”, (1982) p. 336

22) M. Wada, J. Kato, I. Chibata, Eur. J. Appl. Micros biol. Biotechnol., 8, 241 (1979)

23) S. Moriyama, S. Kataoka, K. Nakanishi, R. Matsuno, T. Kamikubo, Agric. Biol. Chem., 44, 2737 (1980)

24) A.M. Klibanov, Anal. Biochem., 93, 1 (1979)

25) K. Martinek, A.M. Klibanov, V.S. Goldmacher, A.V. Tchernysheva, V.V. Mozhaev, I.V. Berezin, B.O. Glotov., Biochim. Biophys. Acta, 485, 13 (1977)

26) K. Martinek, A.M. Klibanov, V.S. Goldmacher, I.V. Berezin, Biochim. Biophys. Acta, 485, 1 (1977)

27) V.P. Torchilin, A.V. Maksimenko, V.N. Smirnov, I.V. Berezin, A.M. Klivanov, K. Martinek, Biochim. Biophys. Acta, 567, 1 (1979)

28) V.P. Torchilin, A.V. Maksimenko, V.N. Smirnov, I.V. Berezin, A.M. Klivanov, K. Martinek, Biochim. Biophys. Acta, 522, 277 (1978)

29) V.P. Torchilin, A.V. Maksimenko, V.N. Smirnov, I.V. Berezin, K. Martinek, Biochim. Biophys. Acta, 568, 1 (1979)
30) A.-C. Koch-Schmidt, K. Mosbach, Biochemistry, 16, 2101, 2105 (1977)

31) Y. Kawamura, K. Nakanishi, R. Matsuno, T. Kami= kubo, Biotechnol. Bioeng., 23, 1219 (1981)

32）土佐哲也 “酵素工学研究会第 9 回講演会” (1982) p. 10

33）福島 達, “酵素工学”, 福井三郎, 千畑一郎, 鈴木周一 編, 東京化学同人 (1981), p. 285

34）楠浩一郎, “酵素工学”, 福井三郎, 千畑一郎, 鈴木周一 編, 東京化学同人 (1981), p. 309

35) S. Frusaki, T. Miyauchi, J. Chem. Eng. Japan. 14, 479 (1981)

36）土佐哲也, 細胞工学, 2, 353 (1983)

37）千畑一郎, 土佐哲也, “固定化酵素” 福井三郎, 千畑一郎, 鈴木周一編，東京化学闰人 (1981), p. 373

38) M. Pastore, F. Morisi, A. Viglia, J. Daily Sci., 57, 269 (1974)

39) K. Nakanishi, R. Matsuno, K. Torii, K. Yamamoto, T. Kamikubo, Enzyme Microb. Technol., 5, 115 (1983)

40) M. Asada, K. Yamamoto, K. Nakanishi, R. Matsuno, A. Kimura, T. Kamikubo, Eur. J. Appl. Microb. Biotechnol., 12, 198 (1981)

41）谷口正之, 中村弘子, 田中三男, 松野隆一, 上久保正, “日本醴酵工学大会要旨集” (1982) p. 250

42）上久保正, 松野隆一, 化学工学, 47, 291 (1983)

43）松野隆一, 中西一弘, 上久保正, 浅田雅宣, “化学工学協 会秋季大会講演要旨集”, (1982) p. 110

44）中西一弘, 松野隆一, 上久保正, “日本農芸化学会大会講 演要旨集”, (1983) p. 480

45) K. Hashimato, S. Adachi, H. Noujima, Y. Ueda, Biotechnol. Bioeng., 25, 2371 (1983) 